ISSN: $2455-104 X$

DOI: $10.26761 /$ IJRLS.6.1.2020.1299

Volume 6, Issue 1 (Jan-June) 2020, 1-10, Paper ID: IJRLS-1299

Received: 17 April. 2020 ; Accepted: 27 April. 2020 ; Published: 29 April. 2020

\title{
An Investigation into the Challenges and Opportunities in the Social Capital Creation by Public Libraries in Northern Nigeria: Cluster Analysis
}

\author{
Abubakar Ladan ${ }^{1}$; Dr. P. Rajendran ${ }^{2}$ \\ Research Scholar, Department of Library and Information Science, SRM Institute of Science and \\ Technology, Kattankulathur, 603203, Tamil Nadu, India ${ }^{1}$ \\ Umaru Musa Yar adua University, PMB 2218 Katsina, Nigeria ${ }^{1}$; \\ Research Supervisor and University Librarian SRM Institute of Science and Technology, \\ Kattankulathur, 603203, Tamil Nadu, India ${ }^{2}$
}

\begin{abstract}
The idea of public libraries as among the institutions for creating social capital has recently attracted the attention of researchers in library and Information Science to find the contribution of public libraries in the creation of social capital. This study examined the availability of information resources and facilities for creating social capital, the challenges of public libraries in Northern Nigeria in the creation of social capital, and solutions to the identified challenges. Survey research was used for the study and questionnaire was used to collect data from the 158 librarians of public libraries under study. Cluster analysis was used to analysed the data collected. The findings of the study revealed that lack of adequate information resources (both print and e-resources), lack of facilities.Lack of library understanding and role to be played in the services and programs contributing to social capital creation, inadequate financial support for public libraries to provide resources and facilities for social capital activities as the highly significant challenges associated in the creation of social capital. Provision of open spaces for open programs and provision of adequate financial support to public libraries were identified as the possible and feasible solutions to addressed the challenges of public libraries in creating social capital.
\end{abstract}

Keywords: Investigation, challenges, opportunities, social capital, Nigeria, Cluster Analysis

\section{INTRODUCTION}

Public libraries are known to provide diverse and increasing variety of services and activities in response to individuals'and community needs. Public library services could be classified into two groups: traditional library services like circulation service, reference service, serial service, lending service and children service; and nontraditional services that is community social activities which include cultural activities, exhibitions and display, 
children activities, film show, school quiz and debates, provision of meeting places and other community social activities.

The realization of public libraries as places for generating social capital has attracted the researchers in Library and Information Science LIS to study how public libraries contribute in the creation of social capital and what mechanisms can be used. Appraising the strategies of generating social capital by public libraries, [1] identified outreach programs, provision of meeting places, provision of universal services and library as community centre. The function of Nigerian public libraries as institutions providing various services and open to all including adult and young people, students, researchers, artisans, business people, farmers, prisoners, worker, children without any restriction or discrimination, demonstrate the potentialities for public libraries in generating social capital. The library services cannot be rendered without adequate needed resources and facilities. Unfortunately, a number of issues restrict provision of efficient and effective public library services in Nigeria. The purpose of this study is to analyse the challenges and opportunities of public libraries in Nigeria in the provision of services and activities that can generate social capital.

\section{PUBLIC LIBRARIES AND SOCIAL CAPITAL}

The idea of public libraries and social capital was started during the American Library Association Conference in 2001 when Kranich, the president of American Library Association chided Putnam for missing to mention in his book Bowline Alone libraries as among the public places for generating social capital. She further said, the provision of public place is the primary way that public libraries build social capital, [2].

Social capital according to [3] refers to links between people in society- "networks, norms and trust"- which produce positive outcomes for the community as a whole. Social capital facilitates individual or collective action generated by networks of relationships, reciprocity, trust and social norms [4]. In another view, [5] identified three forms of social capital which include bonding social capital- bringing people together who already know each other with the goal of strengthening the relationships that already exist. The second form is bridging social capital- a social relation with more friends that are distant, associates and colleagues and the third form is linking social capital- a social relation that involve networks and ties with individuals, groups or corporate actors represented in public agencies, schools, business interest, religious and political groups.

Accordingly, public libraries are among the public institutions that are considered the most efficient generators of social capital [6]. They provide spaces that facilitate social activities, for example, spaces where members of the community can meet, interact, discuss and share ideas. Face-to-face interaction or contact establish trust and generate social capital

\section{LITERATURE REVIEW}

[7] reviewed public library roles and pointed out three services of public libraries which include provision of information resources to users; provision of reading materials; and provision of formal and informal meeting place. [8] believed that the services of public libraries differ in terms of responsibilities, which include individual support and development, commerce, and social and cultural advancement.

Public libraries are powerful instrument for generating social capital. They stand for public information centres, meeting places, community social centres and universal public institutions providing services to all. [9] believed that public libraries are essential in creating social capital for meeting community educational and information needs, by facilitating meetings, provision of informal meeting places, making links between groups in the community and creating a welcoming environment. 
[10] found that the information resources in public libraries in Nigeria were inadequate and out dated. Libraries have been challenged with low patronage due to poor infrastructural facilities and lack of government concern. A study by [11] pointed out that student and other readers of Kwara state public library go to library with their reading materials because most of the materials in libraries are outdated and replaced with the current ones.

Library facilities are important in the provision and utilization of library services. However, the function of public library can only be fulfilled when the libraries are well provided with modern facilities like buildings and spaces, furniture, good lightening, information resources, internet/ICT facilities and children facilities. [12]describe library facilities as buildings, spaces, reading facilities, carrels, book shelves, periodical racks, library spaces, fans and air conditions, lightening, photocopy facilities, computers, and vehicle parking space.

The successful provision of library services and use largely depend on available library resources and facilities. Several studies on public libraries in Nigeria have shown that public libraries in Nigeria are not able to provide required service due to inadequate facilities and lack of government concern. [13] stated that library facilities of Edo state central library of Nigeria were inadequate and poor. However, the importance of ICT facilities in the provision of library services cannot be over emphasised. [14] describes the status of ICT facilities in Nigerian public libraries is still at infant stage and call the need for the libraries to acquire and install computer and software to provide various library services.

Despite the long existence of public libraries in Nigeria, most of its objectives are yet to attain due to a number of challenges militating against them. Some of these prevalent challenges include absences of library services in rural communities, lack of qualified library personnel, inadequate/ inappropriate information resources, and poor library infrastructural facilities[15-18]. All these revolve around the lack of government concern towards public libraries.

By considering the above review of literature with regard to the public libraries as creators of social capital, the possible challenges and opportunities in the task of creating social capital, in this paper an attempt has been made to examine the opinions of the librarians working in the public libraries of Northern Nigeria in this context.

\section{OBJECTIVES OF THE STUDY}

The main objective of this study is to identify and analyse the challenges and opportunities in the creation of social capital by public libraries of northern parts of Nigeria. Specifically, the following objectives are framed:

1. To examine the availability of information resources and facilities in the public libraries of Northern parts of Nigeria

2. To identify the challenges in the creation of social capital by public libraries in Nigeria

3. To examine the solutions to address the challenges.

\section{METHODOLOGY}

The population of the study comprised all the 158 public libraries in Northern Nigeria which include 15 National Libraries of Nigeria, 20 States Public Libraries and 122 branches of state public libraries and one FCT Abuja National library (Headquarters). The study used survey research methods. All the libraries have been considered for the survey thus following Census method of survey.One Librarian was selected from each public library in the 158 public libraries as the target population for the study. The structured questionnaire was used to collect the data. Personal and email administered questionnaire method was used to collect data from the respondents. 


\section{ANALYSIS AND DISCUSSION}

Out of 158 questionnaires distributed to the 3 categories of libraries, only 123 were filled and returned and the response rate is $77.85 \%$.

\subsection{General information about the libraries}

\section{a. Quantum of Library Collections}

Data regarding the quantum of collection in the public libraries of northern Nigeria have been collected. A majority of the libraries (78.05\%) are having collection below 5000 volumes of books. It is very low quantum of collection of books. Only 4 state central Libraries are having between 50001 and 100000 volumes of books, similarly in the case of journals and e-resources. Interestingly more than $75 \%$ of libraries do not have e-resources. This show the public libraries in northern Nigeria are not building collection regularly.

\section{b. Manpower in the Libraries}

The quantum of manpower in the libraries under study is shown that more than $50 \%$ of the branches of state libraries and do not have adequate staff which is not reasonable since library staff play a vital role in the provision of services and in turn administration of the libraries. The fifth law of library science enunciated by Dr.S.R.Ranganathan, Father of library science in India, which reads as "Library is a growing organism" do not fit to public library system in Northern Nigeria, since the staff position as well as collection of libraries are not growing and shows a poor picture. The success of libraries depends on functional collection and effective staff, but this not seen in the libraries under study.

\section{c. Availability of Library Infrastructure}

The availability of library infrastructure in various types of libraries is provided. While the provision of reading table and meeting desks are available in almost all the libraries of National and State Libraries, but it not so in the case branches of state libraries. Some of the ICT based infrastructure such as computers, television, photo copier, printer and scanner are available in majority of libraries. However, the provision of mobile library Van is not seen in most of the libraries in northern Nigeria.

\subsection{Challenges Associated with Public Libraries in Creating Social Capital}

There are number of challenges associated with the public libraries in creating social capitals. In this study sixteen variables were identified as the challenges associated with public libraries in social capital creation. The respondents' opinions in the survey from Northern Nigeria have been analysed on Five Point Scaling Technique with parameters strongly agree, agree undecided, disagree and strongly disagree. The variables have been ranked based on WAM (Weighted Arithmetic Mean) Value

\section{Cluster analysis for the challenges associated with public libraries in creating Social capital}

The hierarchical cluster analysis has been applied for the challenges associated with public libraries in creating Social Capital and the resulting Dendrogram is shown as Figure 1. The Dendrogram which has been derived at $92 \%$ distance level, results four meaningful clusters. The four clusters can be named as:

1. Cluster I: Significant Challenges associated in creating social capital

2. Cluster II: Highly Significant Challenges associated in creating social capital

3. Cluster III: Moderately Significant Challenges associated in creating social capital

Cluster IV: Least Significant Challenges associated in creating social capital 


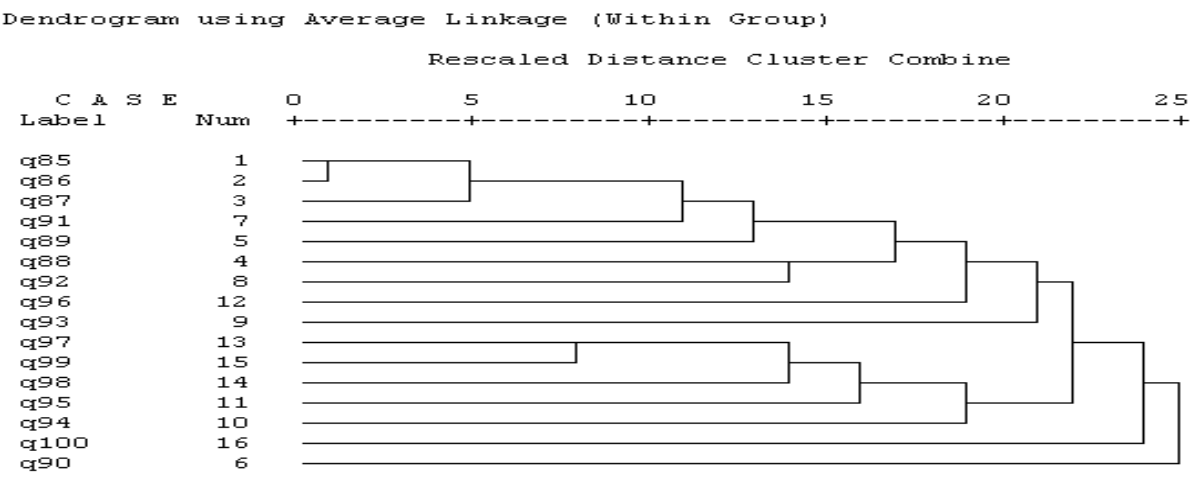

Fig. 1:Dendrogram for the challenges associated with public libraries in creating social capital

Table 1: Cluster I: Significant Challenges associated in creating social capital

\begin{tabular}{|c|c|c|c|c|}
\hline Cluster & Code & Variables & Agree & Disagree \\
\hline I & Q85 & $\begin{array}{l}\text { Lack of proper meeting hall/room to host or organize community } \\
\text { meetings }\end{array}$ & 117 & 6 \\
\hline I & Q86 & $\begin{array}{l}\text { Non availability of open space for festival, social gatherings and } \\
\text { parking spaces }\end{array}$ & 116 & 7 \\
\hline I & Q87 & Inadequate furniture for reading and meetings & 111 & 12 \\
\hline I & Q88 & $\begin{array}{l}\text { Traditional library layout and un-conducive atmosphere of the library } \\
\text { environment to provide library programs and activities }\end{array}$ & 115 & 8 \\
\hline I & Q89 & Lack of community awareness of library functions and services & 116 & 7 \\
\hline I & Q91 & Inadequate and out of date of library collections & 117 & 6 \\
\hline I & Q92 & Lack of governments' concern towards library & 117 & 6 \\
\hline I & Q93 & $\begin{array}{l}\text { Inadequate ICTs infrastructure and facilities for library services and } \\
\text { programs }\end{array}$ & 113 & 10 \\
\hline I & Q96 & Limited library working days and working hours & 113 & 10 \\
\hline & & Total & 1035 & 72 \\
\hline
\end{tabular}

Agree $=1035$ Disagree $=72$ Agree Ratio $=1035 / 123=8.41$ Disagree Ratio $=72 / 123=0.58$ Agree and Disagree Ratio (8.41:0.58) $=14.5: 1$. In Cluster I (Table 1) nine variables have been grouped. The agree and disagree ratio for these variables shown in Table 1 have been arrived at 14.5:1 has shown significant challenges in the creation of social capital, as expressed by the respondent librarians. Hence this cluster has been names as "Significant Challenges associated in creating social capital." 
Table 2 Cluster II: Highly Significant Challenges associated in creating social capital

\begin{tabular}{|l|l|l|l|l|}
\hline Cluster & Code & Variables & Agree & Disagree \\
\hline II & Q94 & $\begin{array}{l}\text { Lack of library understanding and role to be played in the } \\
\text { services and programs contributing to social capital creation }\end{array}$ & 115 & 8 \\
\hline II & Q95 & $\begin{array}{l}\text { Inadequate financial support for public libraries to provide } \\
\text { resources and facilities for social capital activities }\end{array}$ & 120 & 3 \\
\hline II & Q97 & Lack of children's' materials and facilities & 116 & 7 \\
\hline II & Q98 & $\begin{array}{l}\text { Lack of constant power supply to support library services and } \\
\text { programs }\end{array}$ & 115 & 8 \\
\hline II & Q99 & Lack of library vehicles (mobile van) for outreach programs & 118 & 5 \\
\hline & & Total & 584 & 31 \\
\hline
\end{tabular}

Agree $=584$ Disagree $=31$ Agree Ratio $=584 / 123=4.75$ Disagree Ratio $=31 / 123=0.25$ Agree and Disagree Ratio $(4.75: 0.25)=19: 1$. In Cluster II (Table 2) five variables have been grouped. The agree and disagree ratio for these variables shown in Table 2 have been arrived at 19:1 has shown highly significant challenges in the creation of social capital, as expressed by the respondent librarians. Hence this cluster has been names as "Highly significant Challenges associated in creating social capital

Table 3 Cluster III: Moderately Significant Challenges associated in creating social capital

\begin{tabular}{|l|l|l|l|l|}
\hline Cluster & Code & Variables & Agree & Disagree \\
\hline III & Q100 & $\begin{array}{l}\text { Inability of the library heads to adopt } \\
\text { strategies for the social capital activities }\end{array}$ & 112 & 11 \\
\hline
\end{tabular}

Agree $=112$ Disagree $=11$ Agree Ratio $=112 / 123=0.91$ Disagree Ratio $=11 / 123=0.09$ Agree and Disagree Ratio $(0.91: 0.09)=10.11: 1$. In Cluster III (Table 3) one variable has been grouped. The agree and disagree ratio for these variables shown in Table 3 has been arrived at 10.11:1 has shown moderately significant challenges in the creation of social capital, as expressed by the respondent librarians. Hence this cluster has been names as "moderately highly significant Challenges associated in creating social capital.

Table 4: Cluster IV: Least Significant Challenges associated in creating social capital

\begin{tabular}{|l|l|l|l|l|}
\hline Cluster & Code & Variables & Agree & Disagree \\
\hline IV & Q90 & $\begin{array}{l}\text { Inconvenience distance of the library } \\
\text { from the community members }\end{array}$ & 110 & 13 \\
\hline
\end{tabular}

Agree $=110$ Disagree $=13$ Agree Ratio $=110 / 123=0.89$ Disagree Ratio $=13 / 123=0.11$ Agree and Disagree Ratio (0.89:0.11) = 8.09:1. In Cluster IV (Table 4) one variable has been grouped. The agree and disagree ratio for these variables shown in Table 4 has been arrived at 8.09:1 has shown least significant challenges in the creation of social capital, as expressed by the respondent librarians. Hence this cluster has been names as "Least highly significant Challenges associated in creating social capital." 


\subsection{Solutions to Address with the Challenges in Creating Social Capital}

There are number of solutions to address with the challenges in creating social capital. In this study nine variables comprising of solutions associated to overcome with the challenges of public libraries in social capital creation. The respondents' opinions in the survey from Northern Nigeria have been analysed on Five Point Scaling Technique with parameters strongly agree, agree undecided, disagree and strongly disagree. The variables have been ranked based on WAM (Weighted Arithmetic Mean) value

\section{Cluster Analysis for the solutions to overcome with the problems/challenges in creating social capital}

The hierarchical cluster analysis has been applied for solutions associated to overcome with the challenges of public libraries in social capital creation and the resulting Dendrogram is shown as Figure 2. The Dendrogram which has been derived at $60 \%$ distance level, results four meaningful clusters. The four clusters can be named as:

1. Cluster I: Possible and feasible solutions to overcome with the challenges in creating social capital

2. Cluster II: Least possible and feasible solutions to address with the challenges in creating social capital

3. Cluster III: Most least possible and feasible solutions to address with the /challenges in creating social capital

4. Cluster IV: Most possible and feasible solutions to address with the challenges in creating social capital

Dendrogram using Average Linkage (Within Group)

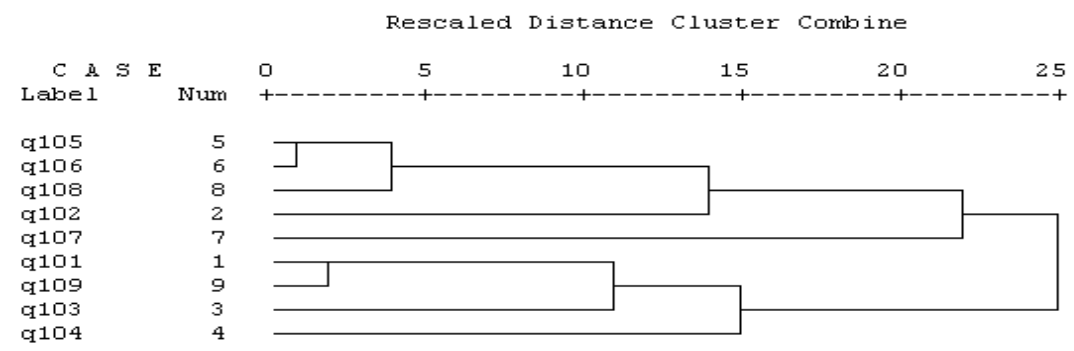

Fig. 2: Solutions to address with the challenges in creating of social capital

Table 5: Cluster I: Possible and feasible solutions to address with the challenges in creating social capital

\begin{tabular}{|l|l|l|l|l|}
\hline Cluster & Code & Variables & Agree & Disagree \\
\hline I & Q102 & $\begin{array}{l}\text { Provision of open spaces for festivals, social gatherings and } \\
\text { parking }\end{array}$ & 115 & 8 \\
\hline I & Q105 & $\begin{array}{l}\text { Provision of ICTs infrastructure and facilities for library } \\
\text { services and programs }\end{array}$ & 123 & 0 \\
\hline I & Q106 & Provision of adequate financial support to public libraries & 118 & 5 \\
\hline I & Q108 & $\begin{array}{l}\text { Provision of constant power supply to support library services } \\
\text { and programs }\end{array}$ & 116 & 7 \\
\hline & Total & 472 & 20 \\
\hline
\end{tabular}

Agree $=472$ Disagree $=20$ Agree Ratio $=472 / 123=3.84$ Disagree Ratio $=20 / 123=0.16$ Agree and Disagree Ratio (3.84:0.16) $=24: 1$. In Cluster I (Table 5) four variables have been grouped. The agree and disagree ratio for these variables shown in Table 5 have been arrived at 24:1 has shown possible and feasible solutions to address with the problems/challenges in creating social capital. Hence this cluster has been names as "Possible and feasible solutions to address with the challenges in creating social capital." 
Table 6 Cluster II: Least possible and feasible solutions to address with the challenges in creating social capital

\begin{tabular}{|l|l|l|l|l|}
\hline Cluster & Code & Variable & Agree & Disagree \\
\hline II & Q107 & Extension of library working days and working hours & 116 & 7 \\
\hline
\end{tabular}

Agree $=116$ Disagree $=7$ Agree Ratio $=116 / 123=0.94$ Disagree Ratio $=7 / 123=0.06$ Agree and Disagree Ratio (0.94:0.06) = 15.66:1. In Cluster II (Table 6) one variable has been grouped. The agree and disagree ratio for this variable shown in Table 6 has been arrived at 15.66:1 has shown least possible and feasible solutions to address with the challenges in creating social capital. Hence this cluster has been names as "Least possible and feasible solutions to address with the challenges in creating social capital."

Table 7 Cluster III: Most least possible and feasible solutions to address with the challenges in creating social capital

\begin{tabular}{|l|l|l|l|l|}
\hline Cluster & Code & Variables & Agree & Disagree \\
\hline III & Q101 & $\begin{array}{l}\text { Provision of meeting rooms/halls to host } \\
\text { or organize community meetings }\end{array}$ & 114 & 9 \\
\hline III & Q103 & $\begin{array}{l}\text { Provision of adequate furniture for } \\
\text { meetings and movable furniture readings }\end{array}$ & 112 & 11 \\
\hline III & Q109 & $\begin{array}{l}\text { provision of library vehicles (mobile van) } \\
\text { for outreach programs }\end{array}$ & 117 & 6 \\
\hline & Total & 343 & 26 \\
\hline
\end{tabular}

Agree $=343$ Disagree $=26$ Agree Ratio $=343 / 123=2.79$ Disagree Ratio $=26 / 123=0.21$ Agree and Disagree Ratio (2.79:0.21) = 13.28:1. In Cluster III (Table 7) three variables have been grouped. The agree and disagree ratio for these variables shown in Table 7 have been arrived at 0.23:1 has shown most least possible and feasible solutions to address with the challenges in creating social capital. Hence this cluster has been names as "Mostleastpossible and feasible solutions to address with the challenges in creating social capital."

Table 8 Cluster IV: Most possible and feasible solutions to address with the challenges in creating social capital

\begin{tabular}{|l|l|l|l|l|}
\hline Cluster & Code & Variables & Agree & Disagree \\
\hline IV & Q104 & $\begin{array}{l}\text { Provision of adequate library collections } \\
\text { and facilities including children's materials }\end{array}$ & 119 & 4 \\
\hline
\end{tabular}

Agree $=119$ Disagree $=4$ Agree Ratio $=119 / 123=0.97$ Disagree Ratio $=4 / 123=0.03$ Agree and Disagree Ratio $(0.97: 0.03)=32.33: 1$. In Cluster IV (Table 8) one variable has been grouped. The agree and disagree ratio for these variables shown in Table 8 has been arrived at 32.33:1 has shown most possible and feasible solutions to address with the challenges in creating social capital. Hence this cluster has been names as "Most possible and feasible solutions to address with the challenges in creating social capital. 


\section{An Investigation into the Challenges and Opportunities in the Social Capital Creation by Public Libraries in Northern Nigeria: Cluster Analysis}

\section{SUGGESTIONS}

Based on the finding of the study the authors recommend the following suggestions which the public libraries in northern Nigeria can venture in the direction of overcoming the challenges in the creation of social capital.

- Public libraries shall provide a public sphere which facilitates to host civic events where public will be allowed to express their opinion on various aspects of social, economic, cultural, religious, scientific aspects.

- Public libraries shall promote culture through informal meetings to promote bridging social capital and ensure unity in the community.

- Public libraries shall provide space for groups which encourage, community to utilize the space in the library to meet and deliberate on various aspects of social and economic development.

- Public library staff shall imbibe positive attitude and customer friendly in the provision of information services.

\section{CONCLUSION}

The greater seriousness of the public libraries in northern Nigeria with regard to the creation of social capital and their role draw much public attention and support. The government of Nigeria should increase subvention of public libraries to meet the public expectations and demand for information and other related issues. For this purpose, necessary funds, facilities,staff and other infrastructure shall be made available so that the public libraries can function effectively both by providing information services and better creation of social as well. The librarians surveyed in this study have expressed their concern with regards to the challenges they face in the conduct of activities and programmes in the direction of creation of social capital. In turn they also suggested possible solutions to overcome the problems and challenges in the direction. It is hoped that the government authorities of Nigeria would provide the ways and means to achieve the goals of public libraries in right perspective.

\section{REFERENCES}

[1] Ferguson, S. (2012). Are Public Libraries Developers of Social Capital? A Review of Their Contribution and Attempts to Demonstrate it, The Australian Library Journal, 61 (1): 22-32.

[2] Kranich, Nancy. (2001). Libraries create social capital. Library Journal, Nov. 15: 40-41.

[3] Putnam, R. D. (1996). The strange disappearance of civic America, American Prospect, 24 (15), pp. 34-48.

[4] Coleman, J. S. (1998). A Rational Choice Representative on Economic Sociology. in Smelser, N. J and Sweaberg R. (Eds). The Handbook of economic sociology. Printon University press, New York.

[5] Woolcock, M. (2001). The place of Social Capital in Understanding Social and Economic Outcomes [PDF] Available:http://www.oecd.org/innovation/research/1824913.pdf

[6] Varheim, A. (2007). Social Capital and Public Libraries: The Need for Research. Library and Information Science Research, 29(3): 416-428.

[7] Chen, T. T. And Ke H. R. (2017). Public Library as a place and breeding ground of social capital: a case study of Singang library. Malaysian Journal of Library and Information Science, 22(1), 45-58.

[8] Agbo, \&Onyekweodiri, N. E. (2011). The Professional Visibility of the Nigerian Library Association: A Report of Survey Findings.

[9] Miller, J. (2014). A Comparative Study of Public Libraries in Edinburgh and Copenhagen and Their Potential for Social Capital Creation. International Journal of Libraries and Information Studies, 64 (4): 316-324.

[10] Ikenwe, I. J. and Idowu, A. (2014). Utilization and user satisfaction of public library services in south-west, Nigeria in the $21^{\text {st }}$ century is a survey, International Journal of Library Services, 3(1): 1-6. improving-public- libraries-innigeria

[11] Taiwo, S. H and Rachel, A. B. (2012) An assessment of information Utilization and Services Delivery in Public Libraries in Kwara State Library Experience. Middlebelt Journal of Library and Information Science, 10 (1): 191-205.

[12] IFLA. (2001). The Public Library Service: IFLA/UNESCO Guidelines for Development, Munchen: Saur 
[13] Iwhiwhu, B. E. and Okorodudu, P. O. 2012. Public library information resources, facilities, and services: user satisfaction with the Edo State central library, Benin-city, Nigeria. Library Philosophy and Practice 747: 1-15. Available: http://digitalcommons.unl.edu/libphilprac/747/

[14] Jacintha, E. U. (2013). Re-equipping the Nigerian Public Library System and Services for the Century. International Journal of Library and Information Science, 5(10), pp. 300-305, https://www.academicjournals.org/IJsLIS.

[15] Iwe, J. I. 2003. Libraries and information in sustainable rural development in Nigeria. Information Development 19(3): 169-177.

[16] Opara, U. N. 2008. The public library in contemporary Nigeria: challenges and the way forward. IFLA Journal 34(4): 349-358. Available: http://journals.sagepub.com/doi/pdf/10.1177/0340035208099270

[17] Abdulkarim, M. (2010). Improving public libraries in Nigeria. Daily Trust, 09 June, 1, col. 1. Available: https://www.dailytrust.com.ng/weekly/index.php/comments/8854-

[18] Obinyan, G. A., Obinyan, O. O. and Aidenojie, E. 2011. Use of information resources in four branches of a state public library in Nigeria. Chinese Librarianship: an International Electronic Journal 31: 1-16. Available:

http://www.iclc.us/cliej/cl310OA.pdf.ss 